\title{
The role of railway stations in increasing transport demand
}

\author{
M. Petrović ${ }^{1}$, V. Jenić ${ }^{1} \&$ D. Kaužljar ${ }^{2}$ \\ ${ }^{I}$ Faculty of Transport and Traffic Sciences, Croatia \\ ${ }^{2}$ Croatian Railway Infrastructure d.o.o., Croatia
}

\begin{abstract}
The monopoly of the railway companies and rigid railway regulations and carrier tariffs at the majority of the European railways have significantly contributed to the drastic reduction in the share of railway traffic in surface transport across all of Europe. Many years of stagnation and the absence of investment into railway transport, particularly regarding railway stations as well as other useful structures along the railway lines of a similar or same function, have led to the neglect and uselessness of these facilities in the railway system. High maintenance prices affect additional neglect, even destruction of railway stations and other buildings on the railway grounds, and construction of functional roofed platforms for passenger handling. Regardless of the fact that in their past, the construction of railway lines was the stimulator of the development of various regions and towns, today railway stations have become unattractive places where people stay just for a short time and only in transit, which is much the case in the Republic of Croatia, but it should be pointed out that even the developed countries have similar problems. The approaching and opening of railway companies to the passengers, as well as the local government, is the priority for serious market competition with competitive road transport. In order to achieve this, a crosssection of the current condition of the basic function of railway companies in the transport of passengers should be made. The introduction and development of integrated transport of passengers is the next step in the creation of competitive supply of the railway companies. The separation of railway carriers from railway infrastructure means also recognition of the important role of infrastructure management in transforming the railway stations from neglected and unattractive places to places with multifunctional facilities. In the first step it is necessary to make a cross-section of the current additional facilities at railway stations, and
\end{abstract}


then to design and supply new facilities motivating the existing passengers to stay longer at the station, and also attracting new users towards stations, i.e. passenger trains. In the future, apart from the traffic function, the railway stations, as gateways to the cities, need to also take over a part of the economic, commercial, cultural, sport and other social functions of the city.

Keywords: railway station, market competition, passenger transport, additional facilities, increasing demand.

\section{Introduction}

The monopoly of the railway companies, poor adaptability to users' requirements and rigid railway regulations and carrier tariffs in the majority of European railways have significantly contributed to the drastic reduction in the share of railway transport in surface transport (traffic) across Europe. Many years of stagnation and no investments into the railway traffic, with special consideration of railway stations, including other useful structures along the railway line of similar or same functions, have led to neglect and inapplicability of these stable means in the railway system. High maintenance prices lead to further neglect and even destruction of the railway stations and other facilities on the railway land and the construction of functional roofed platforms for passenger handling.

As much as the construction of railway lines in the past meant the stimulation of the development of various regions and cities, today the railway stations have become unattractive places where people stay for short periods of time and are mainly only in transit, which much the case in the Republic of Croatia. If the neglect of railway lines and poor exploitation characteristics of local and regional lines is added to this condition, the users' interest to use rail transport is additionally threatened, leading eventually to complete closure of railway traffic on individual relations and to closure of non-profitable lines. It should be emphasized that even the more developed countries and railway authorities have problems similar in nature with the railway lines of low usability, cost-efficiency and profitability. In such operating conditions, even in spite of significant advantages regarding safety and protection of the environment, the railway traffic continues to be the least competitive of carriers in road traffic.

The separation of railway carriers from railway infrastructure means also the recognition of the important role of infrastructure management in transforming the railway station from neglected and unattractive places into places providing multi-functional facilities. In the first step it is necessary to make a cross-section of the existing additional facilities in railway stations, and then to design and offer new facilities that motivate the current passengers to stay longer at the railway station, and attract new, potential users i.e. passengers towards railway stations, i.e. transport by passenger trains. In the second step, the infrastructure managers have to approach the local authorities in visualising the railway stations as structures of economic, commercial, cultural, sport and other social facilities and functions especially of the centres themselves, as well as the wider city area. 
The importance of the role of railway carriers in passenger transport can be found in getting the railway traffic closer to its current as well as potential new users. The coming closer and opening of the railway companies to the passengers is the priority for a more serious market competition with competitive carriers in road transport. In order to achieve this, it is necessary to make in the first step a cross-section of the current condition of the basic functions of railway companies in passenger transport. The introduction and development of integrated passenger transport is one of the next steps, phases in creating a competitive offer of railway companies.

The development of local and regional lines in the future will be impossible without support and financial means of EU funds for regional development. Therefore, the infrastructure manager and railway carriers should act jointly towards local authorities in visualising the railway stations as city gates, where in the future various economic, cultural and other functions important for the city, passengers and citizens would be performed. With this objective, the current condition of railway stations should be analyzed, with an analysis using the examples of successfully reconstructed European railway stations, as well as an overview of the future new facilities at railway stations in the field of railway authority in the Republic of Croatia.

\section{Current condition of railway stations}

\subsection{Construction of railway lines and stations}

Long ago, the construction of traffic routes depended on the geographical characteristics of the regions through which they passed so that the majority of inhabitants stayed at smaller settlements in the hilly regions where the climate was more suitable for agriculture and stock breeding, and the traffic routes were constructed in the lowlands that are suitable for the development of big cities, especially in the regions where several traffic routes intersect. A similar situation was also with the construction of the railway network in the Republic of Croatia with the European Corridor $\mathrm{X}$ and a larger part of Corridor $\mathrm{Vb}(\mathrm{Vc}$ in one section of RH) passing mostly along the lowlands of the country. The construction of railway traffic routes has stimulated also the movement of a part of population into the lowland regions with their employment related to railway transport. The second phase saw the construction of railway lines on the one hand through the hilly regions in order to connect smaller settlements which accommodated a large number of population and through mountain regions in order to connect the continental parts with the seaports. These lines, due to more difficult geographic region, featured also poorer exploitation characteristics but they passed through the existing settlements which eventually led to the reduction of the number of transported passengers. Table 1 shows a classified review of railway stations and other traffic places of work according to the line categories, which indicate that at local and regional lines there are fewer and fewer classified ones in the railway station group. 
Table 1: Total number of rail stations and other types of traffic places of work according to line categories.

\begin{tabular}{|c|c|c|c|}
\hline \multirow{2}{*}{$\begin{array}{c}\text { Traffic places of } \\
\text { work }\end{array}$} & \multicolumn{3}{|c|}{ Types of railway lines } \\
\cline { 2 - 4 } & international & regional & local \\
\hline Rail stations & 137 & 58 & 40 \\
\hline Dispatching point & 0 & 0 & 1 \\
\hline Stops & 163 & 67 & 102 \\
\hline $\begin{array}{c}\text { Dispatching } \\
\text { point/stop }\end{array}$ & 1 & 1 & 7 \\
\hline Total & $\mathbf{3 0 1}$ & $\mathbf{1 2 6}$ & $\mathbf{1 5 0}$ \\
\hline
\end{tabular}

Connection of railway lines and railway stations with counties as territorial economic and political units in the Republic of Croatia is presented in Table 2. Thus, one can observe that out of 20 county centres railway lines of international significance pass through thirteen (13) cities, through one (1) of regional significance, and the railway lines of local significance pass through three (3) county centres.

Table 2: $\quad$ Overview of cities and inhabitants per railway line types.

\begin{tabular}{|c|c|c|c|c|c|c|}
\hline \multirow{3}{*}{$\begin{array}{c}\text { Size of city } \\
\text { centres }\end{array}$} & \multicolumn{6}{|c|}{ Type of railway line } \\
\hline & \multicolumn{2}{|c|}{$\begin{array}{c}\text { International } \\
\text { significance }\end{array}$} & \multicolumn{2}{|c|}{ Regional significance } & \multicolumn{2}{|c|}{ Local significance } \\
\hline & Cities & Inhabitants & Cities & Inhabitants & Citizens & Inhabitants \\
\hline \multicolumn{7}{|c|}{ I-County centres } \\
\hline$>100,000$ & 2 & 843,000 & - & - & 1 & 217,000 \\
\hline $\begin{array}{l}50,000- \\
100,000\end{array}$ & 3 & 222,000 & - & - & - & - \\
\hline$<50,000$ & 8 & 244,000 & 1 & 16,000 & 2 & 50,000 \\
\hline \multicolumn{7}{|c|}{ II - Other cities } \\
\hline$>100,000$ & - & - & - & - & - & - \\
\hline $\begin{array}{l}50,000- \\
100,000\end{array}$ & 2 & 113,000 & 1 & 60,000 & - & - \\
\hline$<50,000$ & 9 & 179,000 & 1 & 11,000 & 2 & 28,000 \\
\hline Total & 24 & $1,601,000$ & 3 & 86,000 & 5 & 295,000 \\
\hline
\end{tabular}

The City of Dubrovnik with over 26,000 citizens is one of the rare county centres which cannot be reached by train. Out of other cities with more than 10,000 citizens only six are not connected by a railway line.

On average there are five to ten pairs of passenger trains that operate on local and regional railway lines and ten out of fifteen pairs of passenger trains on international railway lines apart from suburban traffic in the City of Zagreb where also fifty pairs of suburban passenger trains operate.

Table 4 show the passenger transport at annual levels (2005-2008) per railway line types in $\mathrm{RH}$ and their shares (expressed in \%). 
Table 3: $\quad$ Number of trains (pairs) per railway line types.

\begin{tabular}{|c|c|c|c|c|c|}
\hline \multirow{2}{*}{$\begin{array}{c}\text { Type of } \\
\text { railway line }\end{array}$} & \multicolumn{5}{|c|}{ Type of train } \\
\cline { 2 - 6 } & EC & IC & ICN & Fast & Accelerated \\
\hline International & $3 / 3$ & $7 / 7$ & $3 / 3$ & $27 / 26$ & $11 / 6$ \\
\hline Regional & - & $1 / 1$ & - & $6 / 6$ & $4 / 4$ \\
\hline
\end{tabular}

Table 4: $\quad$ Transport of passengers annually per railway line types.

\begin{tabular}{|c|c|c|c|c|}
\hline \multirow{2}{*}{ Railway line types } & \multicolumn{4}{|c|}{ Transported passengers per year } \\
\cline { 2 - 5 } & $\mathbf{2 0 0 5}$ & $\mathbf{2 0 0 6}$ & $\mathbf{2 0 0 7}$ & $\mathbf{2 0 0 8}$ \\
\hline International & $10,115,566$ & $10,598,551$ & $10,743,764$ & $10,780,454$ \\
\hline Regional & $4,618,401$ & $4,275,624$ & $4,017,629$ & $3,775,644$ \\
\hline Local & $1,399,731$ & $1,369,422$ & $1,367,043$ & $1,224,715$ \\
\hline Total & $\mathbf{1 6 , 1 3 3 , 6 9 8}$ & $\mathbf{1 6 , 2 4 3 , 5 9 7}$ & $\mathbf{1 6 , 1 2 8 , 4 3 6}$ & $\mathbf{1 5 , 7 8 0 , 8 1 3}$ \\
\hline
\end{tabular}

\begin{tabular}{|c|c|c|c|c|}
\hline \multirow{2}{*}{ Railway line type } & \multicolumn{4}{|c|}{ Carried passengers per year (share) } \\
\cline { 2 - 5 } & $\mathbf{2 0 0 5}$ & $\mathbf{2 0 0 6}$ & $\mathbf{2 0 0 7}$ & $\mathbf{2 0 0 8}$ \\
\hline International & 62.70 & 65.25 & 66.61 & 68.31 \\
\hline Regional & 28.63 & 26.32 & 24.91 & 23.93 \\
\hline Local & 8.68 & 8.43 & 8.48 & 7.76 \\
\hline Total & $\mathbf{1 0 0 , 0 0}$ & $\mathbf{1 0 0 , 0 0}$ & $\mathbf{1 0 0 , 0 0}$ & $\mathbf{1 0 0 , 0 0}$ \\
\hline
\end{tabular}

\subsection{Overview of railway station facilities}

The construction of railway stations and other traffic places of work necessary for regular operation and organization of railway traffic / transport the railways was a unique system; the facilities at railway stations were also common both for the needs of infrastructure management and for the needs of railway carriers. Further in the text only those facilities will be discussed that refer to the transport of passengers, primarily the following facilities:

- waiting lounges,

- $\quad$ passenger ticket offices,

- $\quad$ vestibules (entry and vestibule areas),

- information bureaus and facilities,

- left-luggage offices,

- platforms,

- other service facilities,

and it should be noted that the majority of railway stations and other traffic places of work in the Republic of Croatia function as combined railway traffic / 
transport, i.e. they are places at which and through which the activities for passengers as well as for cargo carriage with certain exceptions are performed.

At all railway stations there are waiting lounges and ticket offices. The waiting lounges as areas in railway station buildings in which passengers stay for shorter or longer periods of time before or after their trips, may be classified according to the frequency and requirements of passengers into waiting lounges of the first or second class, waiting lounges for schoolchildren and others. Also, the waiting lounges are open according to the requirements and have to be heated and lighted. In order to protect them against unnecessary staying there or demolishing, the strict railway regulations limit the stay of passengers there to a maximum of 60 minutes prior to arrival or departure of the train according to the planned i.e. scheduled timetable. Next to the waiting lounges there are passenger ticket offices at which tickets are sold. At the railway stations with lower frequency of travelling, with a smaller number of passengers, the ticket offices are being increasingly closed down, and tickets can be bought onboard trains.

At bigger railway stations there are vestibules as basic areas for passenger handling. The vestibules are functionally connected with all the places that serve for passenger handling, so that in their vicinity there should be: information offices, passenger ticket offices, left-luggage offices, waiting lounges, restrooms, kiosks and other premises and facilities. The vestibules have to be equipped with adequate notices, announcements, instructions, info-counters, that provide the passengers with easier and faster, timely and correct information and orientation at the railway station. Apart from vestibules, bigger railway stations have leftluggage offices that are very often replaced by functional luggage lockers.

Platforms are areas in front of railway station buildings and between the tracks, intended for undisturbed boarding of passengers on the train and their getting off the train i.e. their changing of trains i.e. from one train to another. Like other railway station areas, platforms are also marked by exactly defined notices, fields and symbols. Staying at platforms has also been regulated and limited to 15 up to 20 minutes. Only at departure railway stations are passengers allowed to stay for up to 60 minutes. However, under the existing conditions of equipment and organization of passenger traffic, these restrictions and controls are in practice practically non-applicable and impossible to implement, for at least two reasons; first, because the infrastructural elements of the very railway station buildings and surrounding areas simply do not allow it, and because the implementation of such control, check-in points is not possible due to the lack of technical and technological instruments. The introduction of such elements into the organizational and technological part of passenger transport at railway stations needs to be dealt with in the future.

The growing demand for maximally rational operation of minor railway companies such as the Croatian Railways leads to minimization of all the useful areas at railway stations including also their neglect and demolition, and the railway station buildings are replaced by functional platforms at which container organized areas are set or are being set in order to perform passenger activities, sales of travel documents, tickets and information about schedules and train operation. This orientation towards operation rationalization acts as additional 
de-stimulation, de-motivation and literally rejects potentially new and even the past permanent existing users of passenger transport thus directly resulting in the reduction of traffic and revenues.

\subsection{Location of railway stations in the cities}

Apart from recognizing the basic distinctions between the railway stations on corridor and international railway lines and those on regional and local railway lines, one should emphasise also the differences of railway stations in bigger urban centres and inter-stations (inter-stops) in smaller places. The role of railway stations has changed over time because the very construction of railway lines affected also the population migrations in the following ways:

- big railway stations on corridor railway lines are forerunners to the construction of new cities and were mainly adapted to passengers who come there only in transit,

- major railway stations on local and regional railway lines have high construction and cultural value and an element of urban entities.

Varaždin railway station is an example of a railway station with significant building and cultural value, located as the junction of railway lines of international, regional and local significance. From this aspect this railway station in itself has a much greater significance for the City of Varaždin than the very significance as a traffic centre.

On the other hand the example of Vinkovci railway station shows that it was built as one of the significant junction points on the main railway line of international significance and points of intersecting of five railway lines, but without any special building and cultural value but rather due to its pronounced traffic and functional significance and reasons, and therefore it should be redesigned for useful operation and put into traffic function, i.e. give it practical value as it used to have in the past, naturally, recognizing the meantime change in the traffic flows and their current condition with the evaluation of future flows.

The construction of railway routes and the development of cities have affected therefore in different ways the siting of railway stations in the cities. The railway stations in major cities on corridor lines were originally located on city peripheries but today, with the expansion of cities they have become the components of the centres of these big cities, whereas the positions of railway stations in major cities on local and regional lines have not changed significantly, but their mere architecture is of extreme historic-cultural-heritage value.

\section{New solutions for the reconstruction of railway stations}

In order to find new solutions so as to revive the neglected railway stations it is possible to:

- $\quad$ study and apply positive solutions of successful railways at the global level (EU, Japan, USA),

- design new ideas and facilities. 


\subsection{Positive solutions of railway stations in EU and in the world}

Today, with the availability of different modes of transport, the passenger has the possibility of making choices regarding the price, transport, speed, availability, i.e. all the characteristics that may be brought under the term quality of service of the passenger transport system in general. The quality of services of passenger railway transport system certainly includes also the departing i.e. destination points of travelling which are represented by railway stations. The users are to a certain extent more or less satisfied with the level of services provided by railway station facilities or the lack thereof. An overview of world railway stations has been made and they induce interest of the existing and potential passengers. The passengers emphasise most often the facilities such as luggage areas, 'lost and found' offices, restrooms and showers, restaurants, cafés, exchange offices and different types of shops.

Leipzig - Central Railway Station (Hauptbahnhof) covers an area that is greater than the biggest European railway station, and handles on average 150,000 passengers daily. It was built between 1909 and 1915 but during the Second World War it was severely damaged and reconstructed. During the decline of passenger transport by rail in later years, the German (state) railways (D(B)B) decided to reconstruct the railway station so that today it offers its passengers, apart from historical-cultural-building heritage, also a huge shopping centre with many restaurants in order to make their waiting times as comfortable as possible. In front of the railway station itself there are also the starting points of many bus and tram lines of the city. As part of the railway station sometimes temporary exhibitions dealing with the railway topics are organized.

Berlin - Central Railway Station (Hauptbahnhof) has been classified as a railway station of category 1 which means that the level of service is identical to international airports. Apart from various facilities related to rail, such railway stations usually also provide big shopping centres. The railway station was opened in 2006 and it represents one of the major achievements of modern architecture. During its construction the focus was on the functionality of the building itself, i.e. a good connection of the basic railway and accompanying facilities. A part of the accompanying facilities provided to the users and the visitors are WLAN services of several operators, various types of shops, restaurants, and other servicing facilities.

Nagoya Station is the biggest railway station in Japan and in the world regarding the area it covers. It is characterized by two towers one of which serves primarily as an office building and the other as a hotel. It serves on average 1,120,000 passengers daily and at the same time serves as a bus terminal for many local and intercity lines.

Grand Central Terminal is the main/central railway station in New York which consists of 44 platforms with 67 tracks. The accompanying facilities include various types of restaurants, bars, small private shops and a part of the New York Transit museum. 
Zürich Main Station is the biggest railway station in Zürich which accommodates trains from entire Switzerland and the surrounding countries such as France, Italy, Austria and Germany. The railway station represents a hub for many S-Bahn Zürich lines. Over the weekends the trains operate day and night so that it stays open during the entire period, which is part of the services offered to the customers. Among other accompanying facilities interesting for the passengers, users and passers-by is the shopping centre open also on nonworking days.

\subsection{Additional facilities at railway stations}

Railway stations mentioned in the previous chapter based their development primarily on the financial analysis and traditionally high revenues that served as the basis for the reconstruction of railway stations into modern and functional areas for a large number of existing rail services users. This orientation of development can be applied at Zagreb Main Railway Station for approximately 60,000 passengers daily or at the Split Railway Station which is directly connected to the ferry port.

The major part of the rail network and railway stations in Croatia are facing a number of difficulties due to long year absence of investments into the maintenance and development, severe war destruction (a third of the network was directly exposed to war activities) and the economic crisis and industry destruction, including also the lack of readiness of the Croatian Railways to changes and development. All this has led to a significant reduction in competitiveness of rail companies (poor condition of the rail infrastructure, low permitted and running train speeds as well as obsolete transport means in passenger transport), reduction in revenues and increase in costs for minimal functioning of rail transport.

Should this trend of the decline of rail regional and local transport share continue there will be first of all increasing complete traffic closures, and then also closures of railway lines. Rail regional and local traffic has to base its development in the first phase on the basic social and economic objectives such as improvement of the quality of environment, increase of the level of security, increase of the passenger accessibility towards less and underdeveloped areas and the benefits of the service population.

Apart from positive experiences of the developed rail companies and countries, the development of rail transport in Croatia therefore needs to be found in the new additional facilities which include:

- tourist facilities,

- cultural facilities,

- $\quad$ sport facilities.

Connecting of the rail transport with new tourist facilities is based on:

- geo-traffic location of Croatia as a maritime country which connects Central Europe with the Adriatic Sea, railway stations on the coastline, railway stations in coastal cities (Split railway station is directly connected to the ferry port); 
- mountain and hilly areas of Croatia are desirable destinations of many national and foreign mountaineers, railway stations next to mountain tops and wine roads, in the vicinity of winter resorts and ski resorts (mountaineering along the highest tops of the Croatian counties);

- $\quad$ railway lines pass also along a number of nature parks in Croatia, there are also railway stations next to nationally protected natural heritage, parks and reserves (Plitvice Lakes, Lonjsko polje, Kopački rit and others);

- $\quad$ apart from natural beauties regarding tourism, Croatia also has attractive castles and spas in whose vicinity there are railway lines, railway stations next to old castles (the castle Zrinski-Frankopan in Ogulin or Daruvar Spa, numerous castles in Croatian Zagorje and in Medjimurje).

Major county centres and other cities can connect railway transport with various cultural facilities:

- $\quad$ organization of various exhibitions in railway stations and in the railway station areas (such as wagon-museums e.g. at Donji Kraljevec railway station and museum trains that seasonally or continuously travel along the lines and through railway stations);

- $\quad$ organization of theatre, concert and cinema performances at the houses of culture located in the vicinity of railway stations;

- $\quad$ organization of visits to ZOOs and botanical gardens in the vicinity of railway stations, attractive restaurants, gastronomy, and other specially attractive autochthon and authentic offers (Botanical garden in Zagreb, oldtown Zagreb, Zagorje and other gastronomies).

Connecting of rail transport with sport facilities is based on:

- $\quad$ organized transport of fans during major sport events (fan trains);

- $\quad$ organization of sport events on sport terrains in the vicinity of railway

lines (Bajer lake in Kutina);

- information centres about local sport clubs.

By recognizing special characteristics of regions and centres which accommodate railway lines and their integration directs the activities into the development of railway stations as "city and town gates". Croatia is starting to recognize the significance of this segment in the social-economic-political goals and the significance of rail development in the future.

One of the examples that should be followed also by other railway stations in Croatia in designing the facilities for passengers in rail urban, suburban and intercity transport is the Importanne Centre in Zagreb which is located underground below the level of Zagreb Main Railway Station on several levels.

The exterior area around the railway station accommodates several times a year seasonally in the duration of some ten days various manifestations and interesting offers of actual seasonal events: Easter, Christmas, New Year, spring and others, products of various kinds, ecological, gastro, flower, seasonal-fruits and other offers of domestic green producers of autochthon types of products directly from the rural farms not only from the near but also from the wider surroundings, from all over Croatia. 


\section{Conclusion}

Starting from the development of traffic infrastructure and regional development supported also through the programmes of financial funds of the European Union, one can recognize the following purpose and objects of development projects: reduction of congestion by eliminating the capacity restrictions, improvement of the throughput capacity of the network route or junction, shift of traffic demand towards special traffic modes, completion of the missing routes or poorly connected networks and the improvement of accessibility of goods areas and regions.

The identification of the topic in this paper - "railway stations - city gates" in the Republic of Croatia and the role of railway stations in the growing transport demand as a project for the improvement of rail traffic and regional development form a part of a number of measures that should raise awareness in the current users and attract new users to the railways. It is, therefore, necessary to take as a basis the analysis of the current condition of the railway traffic, assessment of the current and future demand, implementation of positive solutions of the developed rail companies, and the development of new solutions in the field of tourism, culture, and sport within regional and local development frames.

The analysis of the current condition of railway transport refers to the analysis of the condition of railway infrastructure and the analysis of the condition of rail carriers. Railway stations are places of common interest both of the infrastructure managers and rail carriers.

The assessment of the current and future demand represents a complex task in order to determine the area of influence of the development of railway stations as city gates and because of the assumptions regarding competitive modes and alternative solutions. The assessments of possible demand should clear the composition of traffic which is attracted by reconstructed railway stations (current, re-directed or actual traffic), flexibility regarding time and costs and sensitivity of the expected traffic flows (flexibility regarding time and costs of travelling, congestion levels of competitive modes, strategy of competitive modes).

The implementation of positive solutions of the developed rail companies refers primarily to big railway stations with higher operation volumes at which certain conversions of classical waiting lounges, vestibules and other accompanying rail facilities have been converted into functional areas mainly providing services: shops, cafés, restaurants, even hotels. If there is demand for such facilities, the current empty useful areas at railway stations can be redesigned and used.

The development of new solutions in the field of tourism, cultural and sport facilities is primarily the development of cooperation between the rail companies and the local authorities and the local organizations and societies. By recognizing the development of such cooperation, the reconstruction of railway stations would be the first phase in the development of railway traffic which would in turn intensify also the purchase of new transport means in the passenger transport, as well as improve the exploitation characteristics of rail infrastructure. 
An important aspect here is a good marketing approach and very strong interaction and influence between the supply and demand in the rail passenger transport. For countries and rail authorities such as e.g. Croatia, which lack financial means for the necessary modernization of the current and purchase of new (both mobile and stable means, capacities) it is very important to balance the supply and demand and to avoid over-capacities, over-investments, and later poor usability, low productivity.

Before that it is very important, and for this many reasons are found, that the companies involved in passenger rail transport in Croatia, being owned by the state (there are no private carriers yet), plead for an increase in passenger transport because of their revenues-orientation, since otherwise they have difficulties in surviving and represent a great burden to the budget, which is becoming more difficult for the railway, government and passengers, and the passengers in rail transport plead for raising of the total quality of service of the rail carriers (speed, comfort, safety, timeliness, frequency in transport) as well as increase in the offer of attractive accompanying facilities related to the railways.

The role of railway stations as city gates, in the growing transport demand, will be possible only in case an information system of the railway stations is built, which would include various information in the field of transport, including all the points of interest, cultural, architectural and other heritage related to railway stations into city tourist guides, with 'check-ins' already at railway stations with direct starting links-lines-routes of trains with airports, as well as other areas of importance mentioned and discussed in this paper, important both for the service users and for the presentation of the local authorities i.e. county centres and other cities and towns.

\section{References}

[1] Malinović, S. Passenger rail transport, Željeznička tehnička škola u Zagrebu, Zagreb, 1998.

[2] Report on network 2010, HŽ Infrastructure, Zagreb 2009.

[3] Catalogue of special trains, HŽ Croatian Railway, Zagreb, 2007.

[4] Decision on railway lines classification, Official Gazette 81/06, Zagreb, 2006.

[5] Urban-traffic study of road-rail transport system of the wider area of the City of Zagreb - IGH - GF - AF - FPZ - IPV - ŽPD, Zagreb, June 2008.

[6] http://www.hr/hrvatska/zupanije

[7] http://hr.wikipedia.org/wiki/Gradovi_u_Hrvatskoj\#Popis_naselja_ve.C4.87i h_od_10.000_stanovnika_od_1941._do_2007.

[8] http://www.hznet.hr/ 